\title{
On the Reference and Enlightenment of Foreign College Examination Management System to Our Country
}

\author{
Zhixian Wu \\ Wuhan Institute of Technology \\ Wuhan, Hubei, 430205
}

\begin{abstract}
Examination is an indispensable part of education. And it is an important way to examine students' learning effect and teachers' teaching level. Through presenting the disadvantages and shortcomings of examination management system in local institutions of high learning in the context of educational modernization, informatization and standardization in our country, this paper analyzes the examination management system of Harvard University and McGill university and points out those that deserve our learning in foreign well-known colleges in their examination concept, process and evaluation process. It is suggested that it should improve examination management level in our country from three aspects: establishment of grading evaluation, improvement of moral supervision and refinement of administrative regulations so as to provide a reference for the improvement of examination management system in China.
\end{abstract}

Keywords-higher education, examination management, the improvement of system

\section{INTRODUCTION}

Education is the internal driving force of scientific and technological innovation, economic development and social progress. In the process of realizing the great rejuvenation of the Chinese nation, higher education, as the top of the education pyramid, plays a vital role. President Xi Jinping pointed out at the National Conference on Ideological and Political Work in Institutions of High Learning that a strong education makes a strong country. The development level of higher education is an important symbol of a country's development level and potential. As China's economy gradually ushers into a new stage of high-quality development, higher education, as a key link to deliver high-quality talents to the society, also needs to innovate and improve in accordance with social needs.

Examination is an important part of teaching work in institutions of high learning and an important way to examine and evaluate students' ability and teaching effect. With the progress of the times and the change of the demand for talents, there are some defects in the existing examination system. In the development and planning of higher education, how to better design and optimize the examination management process and improve the examination evaluation method in order to guide, promote and enhance the knowledge level and

Fund Project: Research on Standard Management and Data Analysis of Various Examinations in Local Institutions of High Learning from the Perspective of "Double-First Class" Initiative under the teaching research project at college level in Wuhan Institute of Technology (X2017060) quality of students, which is the focus of this paper.

\section{THE SHORTCOMINGS IN THE EXAMINATION MANAGEMENT IN OUR COUNTRY}

\section{A. Examination standard is too general}

Examinations in most institutions of high learning in China are taken in the traditional form, namely written examination, which is relatively simple in form. And students can pass exams with only 60 scores in all colleges. They needn't take the make-up exam if only passing 60 scores. There is no differentiation in scores. Some students jokingly call "long live 60 scores, with one more score wasteful", which vividly reflects the psychology of students in taking exams. As the dividing line of scores is too simple, different colleges and majors and courses with different difficulty are not treated differently, leading to some students' low requirements on themselves. Their purpose of learning is not to improve the level of knowledge and enhance professional quality, but the pursuit of not failing in exams and re-taking course in next semester. Therefore, they have weak self-discipline without study purposes and learning enthusiasm and motivation.

\section{B. Process management is unspecific}

Due to the large number of candidates, there will be a variety of problems caused by personal factors during the examination period. For example, how to deal with late candidates? Candidates with religious beliefs or physical disabilities may have special requirements for the test environment. Some candidates may be absent from the test due to family accidents. What language should students of minor languages or foreign students use? How to deal with these different situations? The examination management regulations in most institutions of high learning are not specific enough to deal with all kinds of special circumstances, nor with standardized approaches, thus leading to supervisors and teachers having no rules to follow in the actual execution and increasing unnecessary workload and tasks on teachers and students in the follow-up process.

\section{Examination concept is paid enough attention to}

One of the more common situations in college exams is that before examinations, students will ask teachers to "narrow down the examination scope" which are thereby the focus of 
their examination review, while those contents excluded from examination scope are ignored by them. This situation is common in many colleges and universities, which is a reflection of teachers and students' lack of respect and attention to the concept of examination. As a fair and just way of evaluation, examination is designed to check the teaching effect of teachers and learning effect of students. If teachers narrow down the examination scope, students will treat knowledge differently. A test paper is difficult to cover all knowledge. Thus it is inevitable for students to have blind zone in knowledge if they do not learn those that are not in test papers.

\section{The punishment for cheating is not strict enough}

In different colleges and different examination centers, there are no unified and standardized exam disciplines for invigilators to use in exam rooms. Some invigilators supervise examination room in a lax manner out of concern for students' psychological endurance. After discovering students' cheating, there is no strict punishment in some institutions of high learning. In China's colleges and universities, students are rarely dropped out of colleges due to their cheating. Their personal integrity is neither associated with their cheating, nor causing bad record on personal credibility. As the punishment mechanism is not strict enough, students keep cheating, thus seriously damaging the fairness and justice of exams. [1]

\section{CASES STUDY OF FOREIGN EXAMINATION MANAGEMENT}

In 2015, the CPC central committee made a strategic decision to accelerate the building of world-class universities and disciplines. The State Council issued the Overall Plan for Promoting the Construction of World-Class Universities and First-Class Disciplines, which means that we should conform to the trend of national prosperity and national rejuvenation, establish a lofty and excellent outlook on development in institutions of high learning and create a world-class universities and disciplines in China's education cause, thus striving to become the leader of global higher education. Therefore, on the basis of carrying out the party's educational policy in an all-round way and persisting in spreading Marxist scientific theory, it is necessary to learn from the world's advanced educational experience in running schools, so that the educational cause in institutions of high learning can be properly- governed, well-managed and developed in an allround way.

In European and American educational environment, universities and colleges attach great importance to students' academic integrity. Orientation Course or Transition training is held among freshmen in foreign universities for one week or so to introduce clearly the definition of plagiarism and cheating and related punishment to freshmen. In addition, before students choose each course, professors will give a general introduction to the contents of courses in class and hand out the outlines of courses to students which clearly mark their punishment for cheating including corresponding treatments for cheatings in various forms. [2]
Harvard University, as the oldest institution of higher learning in the United States, has long been ranked first in the world and has enjoyed a high reputation in the world for a hundred years. McGill University is one of the world's top universities in Canada, which has been ranked the first in the ranking of Canadian universities, and enjoys the reputation of "Harvard in the North". This paper takes these two international top universities as examples to sort out the management mode and evaluation process of college examination:

\section{A. The characteristics of examination management in Harvard University}

\section{1) Strict assessment criteria}

According to Harvard University rules, students must meet a minimum standard, that is, only one failure in the course per semester (the score is qualified from A to $\mathrm{C}$, and unqualified from D to E). Students who fail to meet the minimum standards must drop out for two semesters. Students who have doubts about their scores can request for inquiry to the course teacher, the dean or the leader of the academic committee, but the final grading right belongs to the course teacher. In addition, different colleges have their own evaluation rules. Harvard's economics department, for example, has a tougher rule on examinations, requiring 11 of the 12 basic courses to achieve a grade $\mathrm{B}$ or above. If students do not reach $\mathrm{B}$ in more than one course, then they must retake the course. [3]

\section{2) Strict examination regulations}

Harvard's exam rules are so detailed. Students are not allowed to bring their computers, cell phones or other materials into the bathroom during the exam. In case of fire during the exam, students may take their personal belongings out of the exam room, but they must go to the place designated by teachers before the exam begins for emergency shelter. They mustn't read exam-related materials or discuss exam contents with their classmates in emergency places. If they break these rules, they may be expelled from the university.

For late candidates, they are not allowed to attend exam for thirty minutes late. If they are late in less than thirty minutes, then the chief invigilator has the right to decide whether they can attend exam or not and note down them as absentee. The information on every late arrival will be reported to the examination office.

Different colleges will further elaborate on the charter according to their actual situation. Harvard Law School, for example, requires that all exams must be carried out under the schedule published by the registration office and no changes be made to the time and place of the exam. Adjustments can only be made under special circumstances with special approval from the registration office or the dean of instruction. No teacher or staff member has the right to make adjustments, which ensures fair and just examination. Students who arrive late for the exam will be recorded in the text paper and their scores will be deducted accordingly.

\section{3) Strict academic moral supervision}

Harvard University has a complete Honor Code, which is handed out to new students with corresponding instruction at the beginning of the semester, and when they enroll, they are 
asked if they have read the honor code and are committed to abide by them. During each examination, students will be asked to sign in the text paper with the information that he/she has read and will abide by the honor code. In the event of any violation of the honor code, their grades in courses will be invalid. Students who plagiarize and submit homework or papers that are not written by them will be asked to drop out. It is also considered as violation for students to submit the same course paper to two different courses, and then they are required to drop out.

\section{B. The characteristics of examination management in McGill University}

\section{1) Abundant assessment ways}

McGill University requires that students be assessed in a comprehensive manner, examining the full contents of the courses and requiring that each course be tested more than once. Students' class performance accounts for no more than $10 \%$ of the total grade in the course. Once the score exceeds $10 \%$, teachers must give a clear indication in the course syllabus. At the same time, the proportion of the final exam score should not be less than $25 \%$ or more than $75 \%$. If the score of regular performance accounts for more than $50 \%$ of the total score, then the examination must be conducted during the period of the final examination. These regulations ensure that there is a wide variety of assessment methods and the final score of the course is not solely decided by final examination. [4]

\section{2) Dealing with doubts in a fair way}

McGill University's exam charter states that when a student questions a course's final grade, each student has an opportunity to question the course teacher or the paper-marking teacher, who must explain the grade. If the student is not satisfied with the explanation, he/she has the right to apply for appointment of a fair and competent third party to review the exam papers. Under the premise of fairness, the third party can revise the exam scores. Such a response to complaints has greatly safeguarded the fairness and justice of the examination and the rights and interests of students. Reasonable evaluation of students' academic level can promote and motivate them to improve their learning enthusiasm and urge teachers to treat the examination and paper-marking more seriously.

\section{3) Sound preparation for plan}

McGill University also set up an assistant examiner system. If teachers or chief invigilators cannot hold the test on time due to emergency, the assistant examiner can take the test instead. At the same time, if there is a conflict of interest between invigilators or paper-markers, they cannot participate in the invigilation of exams. Special committee is designated to be responsible for implementing all these regulations. The special committee can deal with the possible emergencies in the examination process, which can effectively reduce the potential conflicts and confusion caused by the errors in the process and is also a manifestation of the mature examination process

\section{4) Humanized safeguard measures}

McGill University has corresponding examination management system for students with disabilities, students with special requirements due to their religious beliefs and students who are delayed due to illness or family accidents. For example, they can apply for postponement of examination, or special safeguard, etc. For students who fail to take the mid-term examination for justified reasons, teachers may increase the proportion of the final examination score in the overall evaluation score as appropriate. Such humanized guarantee measures reflect the humanistic care for students, which is a soft standard of higher education level.

\section{THE ENLIGHTENMENT OF FOREIGN CASES TO THE EXAMINATION MANAGEMENT IN CHINA}

\section{A. It should build classification evaluation and carry out strict examination disciplines}

China can learn from the evaluation system of Harvard University in the examination evaluation, which classifies the scores into five grades (A-E). Each grade can be further classified into $\mathrm{A}+, \mathrm{A}$ and $\mathrm{A}-$. There are different rewards and punishments for different grade. The advantage of this approach is that students can prepare exams with a better sense of purpose. The incentive mechanism for learning is more precise and purposeful.

At the same time, we should be fair and strict in examination. At present, some invigilators do not note down the violations of students in examination and report irregular cases in fear of hurting students' self-esteem. And teachers do not deny narrowing down the examination scope due to their kindness. These behaviors will damage the seriousness of examination. We should refer to the strict examination requirements of Harvard University. Once disciplinary violations are investigated and dealt with, no mercy shall be shown. Those with serious circumstances may be dismissed from school, so as to make the academic atmosphere of colleges more rigorous and realistic.

\section{B. It should intensify punishment for cheating and build moral supervision}

One of the reasons why Chinese institutions of high learning are still prone to cheating is that students do not have a clear idea of cheating and do not think that cheating is related to personal character and morality. Therefore, colleges and universities in our country should work hard to implement the examination regulations and impose strict supervision and evaluation on each process. The rules must be abided by. Any violation of rules must be punished accordingly. The purpose of this is to make students have a sense of awe and be selfrestraint in daily study and life, thus adhering to right values in their future life.

The voluntary compliance with the examination rules reflects the level of students' self-restraint and moral sense, so we should find the inner driving force to sublimate students' moral sense. In western countries, students' compliance with examination regulations is the embodiment of the spirit of compliance with the Contract. [5] Under the moral system in new era in our country, young people are the vanguard of the great rejuvenation of the Chinese nation. President Xi urges the young people to "combine correct moral cognition, selfconscious moral cultivation and positive moral practice and constantly cultivate morality in order to lay a solid moral 
foundation, thus going further in life in a correct way." As the old saying goes: to develop your personality before becoming a talent. The quality level of young students in the examination determines the level of life values. Therefore, institutions of high learning should strengthen the moral cultivation of young students in the process of daily education and examination management and guide them to establish and practice socialist core values through serious examination disciplines.

\section{It should refine regulations on management and reveal care in the details.}

A first-class university must be a university full of peopleto-people care, showing respect for the personality, dignity and value of students everywhere, aiming to improve students' outlook on life and values and revealing its connotation and responsibilities in the details. At present, Chinese universities have no clear appeal mechanism for students who question their scores after the examination. It should learn from McGill University to allow students to request for inquiry. And a thirdparty evaluation system should be introduced to re-grade disputed test papers. In addition, if there is any conflict between students' personal life and the examination, colleges should provide corresponding solutions. Thus, invigilators and teachers can have rules to follow by including these plans into regulations. And humanized management and student-oriented can thereby be carried out in a true sense and the care for students can be reflected in the management process.

\section{CONCLUSION}

Based on the current examination system in institutions of high learning in our country, this paper analyzes the disadvantages and shortcomings of examination management in colleges and universities of our country. By referring to examination management system of foreign first-class universities, it proposed to build classification evaluation system, intensify implementation and punishment and refine regulations. These three feasible improvement measures are of practical significance to improve the level of higher education in China

\section{REFERENCES}

[1] Zhang Youbin, Research on the Examination in Foreign Institutions of High Learning [J]. Journal of Chongqing University (Social Science Edition). 2005 (06) (In Chinese)

[2] Xing Weiquan, On the Enlightenment of Examination Evaluation System in American Institutions of High Learning [J]. Higher Education Forum, 2009(06) (In Chinese)

[3] Harvard College Handbook for Students, available online at https://handbook.fas.harvard.edu/book/minimum-requirements

[4] McGill University Examination Regulations, available online at https://www.mcgill.ca/exams/regulations

[5] Yang Qian, Li Ling. On Reference of Spirit of Contract in American Institutions of High Learning to the Management of Institutions of High Learning in China [J]. Data of Culture and Education, 2018(12) (In Chinese) 